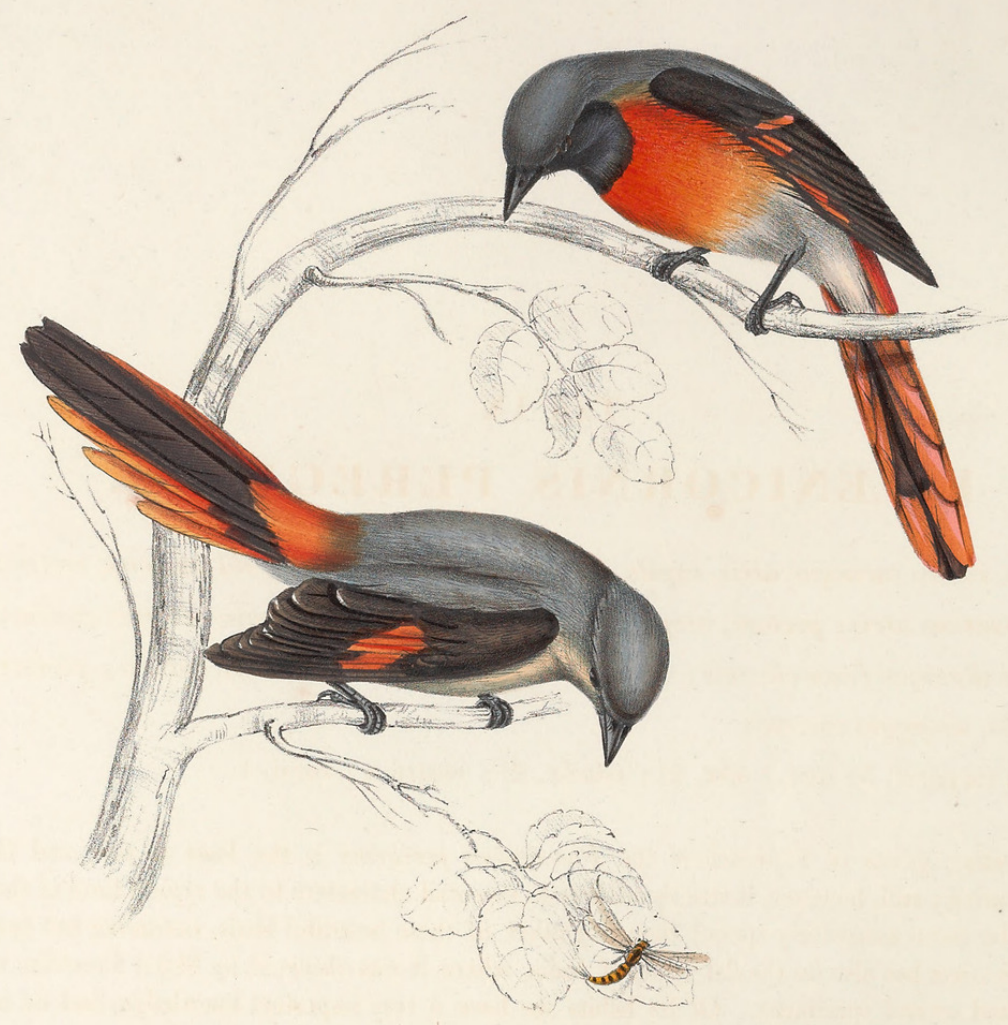

YY U S E PE T T PEREGRINA 
TAB. IX.

\section{PHANICORNIS PEREGRINA.}

Masc. Phoen. rostro tarsisque atris, capite summo dorsoque cinereis; gulâ humeris, rectricibusque mediis quatuor atris; pectore, uropygio, fasciâ alarum rectricibusque externis coccineis.

Fœm. Capite dorsoque fusco-cinereis; alis fuscis, fasciâ aurantiâ obscurè notatis ; pectore florescenti-albo, uropygio coccineo.

Longitudo corporis, $5 \frac{1}{2}$ unc. ; alce, $2 \frac{3}{4} ;$ caudce, $2 \frac{3}{4} ;$ rostri, $\frac{1}{2} ;$ tarsi, $\frac{5}{8}$.

OF this interesting genus of Fly-catchers the Phenicornis peregrina is the least in size, and the most obscure in colouring; still, however, it strictly adheres in essential characters to the typical form of the group. It appears to be more extensively spread than any other of these beautiful birds, occurring not only in the mountainous districts but also on the flat lands of India, where it was observed by Major Franklin, in whose collection we find several specimens. Of its habits we have a very imperfect knowledge, and we are sorry that there are no recorded facts respecting it, upon which we can depend.

The adult male is distinguished by the uniform leaden grey, and the whole of the upper part of the head and back, the cheeks, the throat, shoulders, quills and four middle tail-feathers are black; the breast, the rump, and outer tail-feathers with a small bar on the wings are scarlet; the under parts silvery with a slight wash of orange.

The female is much more uniform in her colouring, wanting the black throat which as well as the upper surface is of a dull grey; the four middle tail-feathers are of a brownish black; the outer tail-feathers, the rump, and a spot in the centre of the wing, pale orange.

The Plate represents a male and female of the natural size. 


\section{$2 \mathrm{BHL}$ Biodiversity Heritage Library}

Gould, John. 1831. "Muscipeta peregrina [Tab. IX]." A century of birds from the Himalaya Mountains -. https://doi.org/10.5962/p.323534.

View This Item Online: https://www.biodiversitylibrary.org/item/132967

DOI: https://doi.org/10.5962/p.323534

Permalink: https://www.biodiversitylibrary.org/partpdf/323534

\section{Holding Institution}

Smithsonian Libraries

\section{Sponsored by}

Biodiversity Heritage Library

\section{Copyright \& Reuse}

Copyright Status: Public domain. The BHL considers that this work is no longer under copyright protection.

This document was created from content at the Biodiversity Heritage Library, the world's largest open access digital library for biodiversity literature and archives. Visit BHL at https://www.biodiversitylibrary.org. 